\title{
Implementation of Prefabrication and Modular Offsite Construction using BIM and Lean Construction Techniques
}

\author{
Michael W. Robey ${ }^{1}$ and Raja R.A. Issa ${ }^{2}$ \\ ${ }^{1} \mathrm{PhD}$ Student, Rinker School of Construction Management, Univ. of Florida, P.O. Box 115703, \\ Gainesville, FL 32611. E-mail: mrobey@ufl.edu \\ ${ }^{2}$ Holland Professor, Rinker School of Construction Management, Univ. of Florida, P.O. Box \\ 115703, Gainesville, FL 32611. E-mail: raymond-issa@ufl.edu
}

\begin{abstract}
The construction industry continues to experience productivity rates that lag behind other industries. Additionally, an increasingly competitive market and a decreasing skilled labor pool are challenging construction firms. Prefabrication and offsite modular construction techniques offer alternatives to traditional site-built construction methods that have the potential to provide improved productivity as well as other added benefits. Prefabrication methods, applied effectively, offer results that produce value to the project team. Such value includes improved productivity and efficiency in construction operations, reduced project costs, reduced schedule durations, and improved safety, increased levels of quality and improved sustainability and waste reduction. Currently the implementation of prefabrication and offsite construction techniques on the construction project remains subjective and unstandardized. The aim of this research is to develop a framework that will assist the project team to make decisions regarding the use of prefabrication and modular construction based on factors that have proven to be the most successful in implementing modern methods of construction. The concentration is on emphasizing the use of Building Information Modeling and Lean Construction methods as catalysts to maximize the effectiveness of the use of modular offsite construction. This research is primarily toward the use of prefabrication and modular construction methods for vertical construction and should prove valuable for all project players including Owners, Designers and Constructors. The development of this framework utilizes information compiled through interviews and case studies to develop a proposed framework for implementing prefabrication and off-site modular construction techniques at the project level. The framework will be validated in the future using a Delphi survey to qualitatively generate quantified data on the best methods to implement prefabrication and offsite construction techniques.
\end{abstract}

\section{KEYWORDS}

Modular and offsite construction, prefabrication, construction productivity, building information modeling, BIM, lean construction

\section{INTRODUCTION}

Construction is a unique industry that has faced continuing challenges over the past few decades. The economic climate in which construction firms operate has become increasingly competitive and unlike in other industries, pricing for construction projects is not necessarily solely determined by the market. Construction firms must vie for projects through a competitive process of selection based on factors that include construction price, experience, reputation, financial stability, and other criteria that may be important to the project owner. 
This competitive nature of the construction industry requires construction firms to continue to seek ways to maintain profitability through improved productivity and efficiency. Productivity is a continuing challenge for construction firms. Construction productivity has been shown to be decreasing over the past two decades while the average productivity for other industries has been increasing over the same time period (Teicholz 2013). Non-construction industries have benefited from the application of computers and technological advancements resulting in increased productivity. The construction industry is notorious for being slow to adopt and implement new technology (Peansupap and Walker 2006).

Prefabrication and modular and offsite construction (PMOC) techniques are being used increasingly on construction projects around the world. Although not a new concept, PMOC techniques are being used increasingly in new ways that are resulting in benefits to the construction process. The current drivers for the use of PMOC are those that result in improvement in the elements of productivity. These drivers for the use of PMOC (McGraw Hill 2011) are: 1) Reduction in project duration; 2) Reduced costs and project budget; 3) Improved worker safety and 4) Improvement in elements of sustainable construction including reduced site impact and reduced waste.

The increase in construction productivity through the use of PMOC techniques is in line with a study performed by the National Research Council (NRC 2009) with the purpose of advancing the competitiveness and productivity of the U.S. construction industry. The results directly referenced prefabrication and offsite modular construction and Building Information Modeling (BIM) while indirectly referencing techniques that relate to Lean Construction. If implemented these techniques have the potential to provide significant advancement in construction productivity.

The focus of this paper is to describe ongoing research having the goal of developing a framework that will facilitate the increased use of PMOC in the construction industry. This study explores the synergies between PMOC and the combined implementation of BIM and Lean Construction methods and their potential to maximize the benefits derived from PMOC use.

\section{RESEARCH METHODOLOGY}

This paper outlines the research in progress to define a framework that will maximize the effectiveness of PMOC techniques. The first step in developing the framework is to identify the opportunities for which BIM is currently being used in the construction process. This is being accomplished through a thorough literature review and by means of ongoing case study research. Additionally, a review of current Lean Construction practices as they are being applied in the construction industry is being conducted to compile a listing of successfully implemented Lean techniques. The resulting compilation of Lean and BIM functionalities is cross referenced and compared to current usage of PMOC techniques as identified in the case studies. A matrix of the interactions of BIM, Lean Construction and PMOC will be developed to identify the key interactions between the three processes that present the greatest opportunities to facilitate the implementation and successful utilization of PMOC techniques. These successful utilization factors will be validated through a Delphi survey. The results will be the basis of the implementation framework for PMOC through the interaction of BIM and Lean Construction. 


\section{DISCUSSION}

\section{Prefabrication and Modular and Offsite Construction (PMOC)}

The Construction Industry continues to search for improved means and methods that will increase productivity, improve profitability, and build sustainably. PMOC techniques, effectively implemented, have shown that they have the potential to accomplish these objectives. The National Institute of Standards and Technology (NIST) commissioned the NRC to study the productivity of the U.S. construction industry. The goal was to make recommendations for improving productivity within the construction industry. The report identified obstacles to productivity within the various functions of the construction industry and developed five related functional activities within construction that could significantly improve construction productivity over the next ten years. The five activities, entitled "Opportunities for Breakthrough Improvements," include increased use of prefabrication, preassembly and modular offsite construction (NRC 2009). Eastman and Sacks (2008) noted that construction has the ability to significantly improve productivity by employing manufacturing technologies through PMOC. As noted earlier PMOC has the potential for tangible benefits in addition to productivity improvement (McGraw Hill 2011).

Many benefits of PMOC can be measured in cost reduction and savings, many other benefits provide value that are not easily quantified in terms of cost. These benefits include improved site utilization, increased quality, increased safety, improved sustainability practices and improved business market competitiveness and continuity (Blismas et al. 2006).

\section{Building Information Modeling}

Over the past decade Building Information Modeling (BIM) has provided significant value to the construction industry (Azhar 2011). BIM has proven to be more than just a tool, it is a process that yields benefits throughout the entire construction project life cycle from design through to occupancy (Aranda-Mena et al. 2009). McGraw Hill Construction reports that $75 \%$ of contractors using BIM are seeing a positive return on investment for their use of BIM (McGraw Hill 2013). Ashar (2011) noted that over $80 \%$ of firms that use BIM have stated that the use of BIM has a very positive effect on their company's productivity.

The benefits that result from the utilization of BIM on construction projects are related to the level of engagement in BIM by the construction firm. The greater extent that a construction firm employs BIM results in greater benefits and greater return on its investment (McGraw Hill 2014). BIM can be defined according to varying levels of usage. For some construction firms BIM is a software tool with utilization limited to the functions of the software. Construction firms that use BIM to its full extent consider it to be a new paradigm in construction project delivery. These firms consider BIM to be a new approach to the practice of construction project delivery and to the development of more effective relationships between parties to the project (Aranda-Mena et al. 2009).

The use of BIM enhances the effectiveness of using PMOC on a project. BIM is a tool that offers dimensional accuracy and stability that are an essential function for modular offsite construction to be effective. As a tool BIM brings the same functionality to PMOC projects as it does to conventional construction. Such functions include visualization, coordination, sequencing, quantification and information sharing. BIM also brings value to PMOC as a process that fosters 
the collaboration necessary for PMOC to be utilized successfully. As a process, BIM brings all project stakeholders together for buy-in to the PMOC process. To effectively utilize BIM, it has to be used within a process that promotes collaboration among all project actors (Gu and London 2010). That collaboration is a synergy that works in both directions. Collaboration is a function of the project management process that will allow for the most effective use of BIM. That collaboration likewise has a beneficial effect on the project management process and ultimately for the project itself. BIM is such an effective tool that fosters collaboration and that collaboration likewise maximizes the effectiveness of that tool and can be utilized for the benefit of the project delivery process (McGraw Hill 2014).

\section{Lean Construction}

The application of Lean Construction techniques is another emerging trend that is demonstrating confirmed improvement of construction productivity. Lean Construction is the application and evolution of a management and organizational philosophy developed by the automaker Toyota. This management philosophy known as the Toyota Production System (TPS) and the Toyota Way, is based on 14 principles developed by Toyota to systematize a methodology for increasing productivity and efficiency in their manufacturing process. The Toyota Production System is being widely applied outside of the manufacturing industry (Gao and Low 2014). The principles of TPS focus on the Value Stream of the organization in providing their goods or services. The objective is to reduce waste and continuously improve the process with the result of maximizing value to all clients. The principles of TPS are being applied with success in the construction industry and are commonly known as Lean Construction. Lean Construction is a management philosophy and a systematic process that can provide benefits in relation to the extent of its application and is most effective when fully implemented throughout the organization.

\section{PMOC Improvement using BIM and Lean Construction}

Lean Construction and BIM are different processes that individually have significant benefits for construction. When utilized in combination on a construction project those benefits are compounded. Sacks et al. (2010) identified 56 interactions between BIM and Lean Construction that provide constructive benefits when used together. Oskouie et al. (2012) identified 22 BIM functionalities that contribute to the effectiveness of Lean Construction techniques. Similarly, Khanzode et al. (2006), detail the benefits of combining the use of visualization models, particularly Building Information Modeling (BIM) with Lean Project Delivery process. The synergy of both processes and techniques add value to implementing prefabrication and offsite construction. A National Research Council (2009) study identified and recommended five opportunities for breakthrough advancement in construction productivity. Those recommended opportunities included the use of prefabrication and modular offsite construction, the increased use of BIM, and improvements in the use of technology, improvements in processes, materials, equipment and information that are directly related to Lean Construction principles.

PMOC techniques have the potential to significantly improve construction productivity. Although PMOC has been in use for many years, it is still a relatively new process in its resurgence during the past decade. Use of PMOC is still relatively low with about $37 \%$ of contractors using it at a high or very high level (McGraw Hill 2011). The decision to use PMOC is typically made late in the preconstruction phase and is based on past experience, anecdotal information, conjecture and hearsay rather than data supported evidence (Li et al. 2014). 
Previous studis have established methodologies to assist and support decision makers in determining the scope of PMOC that can be used on individual projects. Pan et al. (2012) developed weighted, value-based, decision criteria structured to assist in the decision to use prefabrication and offsite construction methods. Murtaza et al. (1993) developed a framework for a computerized, knowledge based decision support tool for implementing PMOC. Additionally, Chen et al. (2010) developed an automated decision support systems including multi-agent systems and the identification of discrete modules extracted from BIM. These methods are dependent on information made available to the support systems and the interests and goals of those involved in the project decision hierarchy. Table 1 shows the results of a preliminary investigation into the currently published research into the synergies between PMOC, BIM and Lean Construction.

Table 1. Preliminary review of published research on the use of PMOC, BIM and Lean Construction synergies.

\begin{tabular}{|c|c|c|c|c|}
\hline Authors & Published research results & PMOC & BIM & Lean \\
\hline Salem 2006 & $\begin{array}{l}\text { Development of a Lean Assessment Tool for } \\
\text { implementing Lean principles in construction. }\end{array}$ & $\checkmark$ & & $\checkmark$ \\
\hline Koskela 1992 & $\begin{array}{l}\text { Application of Lean Construction philosophy in } \\
\text { construction. }\end{array}$ & $\checkmark$ & & $\checkmark$ \\
\hline $\begin{array}{l}\text { Khanzode et al. } \\
2006\end{array}$ & $\begin{array}{l}\text { Virtual design and construction tools, including BIM } \\
\text { are enablers for Lean Production Delivery Process. }\end{array}$ & & $\checkmark$ & $\checkmark$ \\
\hline $\begin{array}{l}\text { Gerber et al. } \\
2010\end{array}$ & $\begin{array}{l}\text { Used case studies to analyze examples of the } \\
\text { interaction of BIM and Lean principles. }\end{array}$ & $\checkmark$ & $\checkmark$ & $\checkmark$ \\
\hline $\begin{array}{l}\text { Moghadam et } \\
\text { al. } 2012\end{array}$ & $\begin{array}{l}\text { Integration of BIM and Lean to support the modular } \\
\text { construction manufacturing process. }\end{array}$ & $\checkmark$ & $\checkmark$ & $\checkmark$ \\
\hline $\begin{array}{l}\text { Sacks et al. } \\
2009\end{array}$ & $\begin{array}{l}\text { Lean construction requirements supported by } \\
\text { computer-aided visualization tools (BIM included). }\end{array}$ & & $\checkmark$ & $\checkmark$ \\
\hline $\begin{array}{l}\text { Sacks et al. } \\
2010\end{array}$ & $\begin{array}{l}\text { Identified } 56 \text { interactions between BIM } \\
\text { functionalities and Lean construction principles. }\end{array}$ & & $\checkmark$ & $\checkmark$ \\
\hline $\begin{array}{l}\text { Oskouie et al. } \\
2012\end{array}$ & $\begin{array}{l}\text { Interaction matrix of Lean principles and BIM } \\
\text { functionalities. }\end{array}$ & & $\checkmark$ & $\checkmark$ \\
\hline $\begin{array}{l}\text { O'Connor et al. } \\
2014\end{array}$ & $\begin{array}{l}\text { Identified } 21 \text { Critical Success Factors and enablers } \\
\text { for implementing modularization. }\end{array}$ & $\checkmark$ & & \\
\hline $\begin{array}{l}\text { Gao and Low } \\
2014\end{array}$ & $\begin{array}{l}\text { Framework of implementation guidelines to integrate } \\
\text { the Toyota Way principles into construction. }\end{array}$ & & & $\checkmark$ \\
\hline Nawari 2012 & $\begin{array}{l}\text { Importance of BIM as a tool for prefabrication and } \\
\text { development of a standard for implementation. }\end{array}$ & $\checkmark$ & $\checkmark$ & \\
\hline $\begin{array}{l}\text { Lu and Korman } \\
2010\end{array}$ & $\begin{array}{l}\text { Identified the benefits of using BIM for planning, } \\
\text { coordination and fabrication in modular construction. }\end{array}$ & $\checkmark$ & & $\checkmark$ \\
\hline $\begin{array}{l}\text { Dossick et al. } \\
2013\end{array}$ & $\begin{array}{l}\text { BIM and Lean principles used in conjunction foster } \\
\text { collaboration, improve communication and } \\
\text { information sharing on Integrated Project Delivery } \\
\text { projects. }\end{array}$ & & $\checkmark$ & $\checkmark$ \\
\hline
\end{tabular}


The research by Gerber et al. (2010) and Moghadam et al. (2012) listed in Table 1, both mention BIM and Lean Construction as support tools for prefabrication and modular manufacturing. They do not focus on the interaction of PMOC, BIM and Lean Construction on the project level and do not offer recommendations on effectively implementing the use of PMOC through the utilization of BIM and Lean Construction. There has been no significant published research into the interaction of PMOC, BIM and Lean Construction concurrently on construction projects.

\section{CONCLUSION}

The Construction Industry continues to search for improved means and methods that will increase productivity, improve profitability, and build sustainably. Prefabrication and Modular Offsite Construction techniques, effectively implemented, have shown that they have the potential to accomplish these objectives. Combined with the use of BIM and Lean Construction, the use of PMOC has the potential to significantly improve the construction process through increased productivity, improved schedule performance, improved quality, increased worker safety, enhanced sustainable construction performance, as well as several additional value added benefits.

The ongoing research described in this paper will help construction firms in the implementation of PMOC techniques on construction projects through the utilization of BIM and the application of Lean Construction methods. Current implementation of PMOC on construction projects is relatively low considering that the value added to the project though the use of PMOC is documented (Lu and Liska 2008, Blismas and Wakefield 2009). Presently, decision-assist methods use weighted rankings and other analytics to select from among modular offsite construction methods to use for a project.

The framework developed will assist construction firms to maximize the effectiveness of implementing prefabrication and offsite modular construction methods. The framework will identify the key benefits of using PMOC as drivers for implementing modular strategies. These will become the variables that will be assessed against the synergies of BIM functionalities and Lean Construction practices. Included in the assessment will be particular aspects of the individual project relevant to implementing PMOC including type of project, symmetry, size, location, design phase and complexity. The framework will identify patterns and synergies between PMOC, BIM, Lean Construction and project specifics that will effectively maximize the benefits of using PMOC and facilitate its implementation.

\section{REFERENCES}

Aranda-Mena, G., Crawford, J., Chevez, A., and Froese, T. (2009). Building information modelling demystified: Does it make business sense to adopt BIM? International Journal of Managing Projects in Business, 2(3), 419-434. doi:http://dx.doi.org/10.1108/17538370910971063

Azhar, S. (2011). Building information modeling (BIM): Trends, benefits, risks, and challenges for the AEC industry Leadership and Management in Engineering, 11(3), 241-252. doi:http://dx.doi.org.lp.hscl.ufl.edu/10.1061/(ASCE)LM.1943-5630.0000127

Blismas, N., Pasquire, C., and Gibb, A. (2006). Benefit evaluation for off-site production in construction. Construction Management and Economics, 24(2), 121-130. doi:10.1080/01446190500184444 
Blismas, N., and Wakefield, R. (2009). Drivers, constraints and the future of offsite manufacture in Australia. Construction Innovation, 9(1), 72-83.

doi:http://dx.doi.org.lp.hscl.ufl.edu/10.1108/14714170910931552.

Chen, Y., Okudan, G. E., and Riley, D. R. (2010). Decision support for construction method selection in concrete buildings: Prefabrication adoption and optimization. Automation in Construction, 19(6), 665-675. doi:http://dx.doi.org.lp.hscl.ufl.edu/10.1016/j.autcon.2010.02.011

Dossick, C., Azari, R., Kim, Y., and El-Anwar, O. (2013). IPD in practice: Sustaining collaboration in healthcare design and construction. (pp. 377-386) American Society of Civil Engineers. doi:doi:10.1061/9780784412909.036

Dubois, A., and Gadde, L. (2002). The construction industry as a loosely coupled system: Implications for productivity and innovation. Construction Management and Economics, 20(7), 621-631. doi:10.1080/01446190210163543

Eastman, C., and Sacks, R. (2008). Relative productivity in the AEC industries in the united states for on-site and off-site activities. Journal of Construction Engineering and Management, 134(7), 517-526. doi:10.1061/(ASCE)0733-9364(2008)134:7(517)

Gao, S., and Low, S. P. (2014). The Toyota way model: An alternative framework for lean construction. Total Quality Management \& Business Excellence, 25(5-6), 664-682. doi:10.1080/14783363.2013.820022.

Gerber, D., Becerik-Gerber, B., and Kunz, A. (2010). Building information modeling and lean construction: Technology, methodology and advances from practice. 18th Annual Conference of the International Group for Lean Construction (IGLC 18).

Goodrum, P. M., Haas, C. T., \& Glover, R. W. (2002). The divergence in aggregate and activity estimates of US construction productivity. Construction Management and Economics, 20(5), 415-423. doi:10.1080/01446190210145868

$\mathrm{Gu}, \mathrm{N}$., and London, K. (2010). Understanding and facilitating BIM adoption in the AEC industry. Automation in Construction, 19(8), 988-999.

doi:http://dx.doi.org.lp.hscl.ufl.edu/10.1016/j.autcon.2010.09.002

Huang, A., Chapman, E., and Butry, D. (2009). Metrics and Tools for Measuring Construction Productivity: Technical and Empirical Considerations. NIST Special Publication 1101, National Institute of Standards and Technology (US), U.S. Department of Commerce, September 2009.

Koskela, L. (1992). Application of the New Production Philosophy to Construction, Technical Report 72 Stanford: Center for Integrated Facility Engineering, Stanford University.

Khanzode, A., Fischer, M., Reed, D., and Ballard, G. (2006). A Guide to Applying the Principles of Virtual Design \& Construction (VDC) to the Lean Project Delivery Process. CIFE, Stanford University Working Paper \#093, December 2006.

Li, Z., Shen, G., Ji, C., and Hong, J. (2014). Stakeholder-based analysis of drivers and constraints in the use of off-site construction. (pp. 26-36) American Society of Civil Engineers. doi:doi:10.1061/9780784413777.004.

Liker, J. K. (2004). The Toyota way: 14 management principles from the world's greatest manufacturer. New York, NY: McGraw-Hill.

Lu, N., and Liska, R. W. (2008). Designers' and general contractors' perceptions of offsite construction techniques in the United States construction industry. International Journal of Construction Education and Research, 4(3), 177-188. doi:10.1080/15578770802494565 
Lu, N., and Korman, T. (2010). Implementation of building information modeling (BIM) in modular construction: Benefits and challenges Construction Research Congress 2010: Innovation for Reshaping Construction Practice, Banff, Alberta, Canada. 1136-1145.

McGraw Hill Construction. (2014). The business value of BIM for construction in major global markets. (Smart Market Report). Bedford, MA: McGraw Hill Construction.

McGraw Hill Construction. (2013). Lean construction: Leveraging collaboration and advanced practices to increase project efficiency. (Smart Market Report). Bedford, MA: McGraw Hill Construction.

McGraw Hill Construction. (2011). Prefabrication and modularization: Increasing productivity in the construction industry. (Smart Market Report). Bedford, MA: McGraw Hill Construction.

Moghadam, M., Singh, G., and Al-hussein,M. (2012). Automation of modular design and construction manufacturing through an integrated BIM/lean model. Gerontechnology, 11(2) Retrieved from http://gerontechnology.info/index.php/journal/article/view/gt.2012.11.02.611.00

Murtaza, M., Fisher, D., and Skibniewski, M. (1993). Knowledge-based approach to modular construction decision support. Journal of Construction Engineering and Management, 119(1), 115-130. doi:10.1061/(ASCE)0733-9364(1993)119:1(115)

Nawari, N. (2012). BIM standard in off-site construction. Journal of Architectural Engineering, 18(2), 107-113. doi:10.1061/(ASCE)AE.1943-5568.0000056

National Research Council (U.S.). Board on Infrastructure and the Constructed Environment, \& National Research Council (U.S.). Committee on Advancing the Productivity and Competitiveness of the U.S. Construction Industry. (2009). Advancing the competitiveness and efficiency of the U.S. construction industry. Washington, D.C: National Academies Press.

O'Connor, J., O'Brien, W., \& Choi, J. (2014). Critical success factors and enablers for optimum and maximum industrial modularization. Journal of Construction Engineering and Management, 140(6), 04014012. doi:10.1061/(ASCE)CO.1943-7862.0000842

Oskouie, P., Gerber, D., Alves, T., and Becerik-Gerber, B. (2012). Extending the interaction of building information modeling and lean construction. IGLC 2012 - 20th Annual Conference of the International Group for Lean Construction, San Diego, California, U.S.A.

Pan, W., Dainty, A., and Gibb, A. (2012). Establishing and weighting decision criteria for building system selection in housing construction. Journal of Construction Engineering and Management, 138(11), 1239-1250. doi:10.1061/(ASCE)CO.1943-7862.0000543

Peansupap, V., and Walker, D. (2006). Information communication technology (ICT) implementation constraints. Engineering, Construction and Architectural Management, 13(4), 364-379. doi:http://dx.doi.org/10.1108/09699980610680171.

Sacks, R., Treckmann, M., and Rozenfeld, O. (2009). Visualization of work flow to support lean construction. Journal of Construction Engineering and Management, 135(12), 1307-1315. doi:10.1061/(ASCE)CO.1943-7862.0000102.

Sacks, R., Koskela, L., Dave, B., and Owen, R. (2010). Interaction of lean and building information modeling in construction Journal of Construction Engineering and Management, 136(9), 968-980. doi:http://dx.doi.org.lp.hscl.ufl.edu/10.1061/(ASCE)CO.1943-7862.0000203.

Salem, O., Solomon, J., Genaidy, A., and Minkarah, I. (2006). Lean construction: From theory to implementation. Journal of Management in Engineering, 22(4), 168-175. doi:10.1061/(ASCE)0742-597X(2006)22:4(168)

Teicholz, Paul. (2013). "Labor-Productivity Declines in the Construction Industry: Causes and Remedies (another Look)." AECbytes Viewpoint \#67. 